\title{
Critical research needs for successful food systems adaptation to climate change
}

\author{
Michelle Miller, ${ }^{\mathrm{a}, *}$ Molly Anderson, ${ }^{\mathrm{b}}$ Charles A. Francis, ${ }^{\mathrm{c}}$ Chad Kruger, ${ }^{\mathrm{d}}$ Carol Barford, ${ }^{\mathrm{e}}$ \\ Jacob Park, ${ }^{\mathrm{f}}$ and Brent H. McCown ${ }^{\mathrm{g}}$
}

Submitted June 14, 2013 / Revised August 23, 2013 / Published online September 4, 2013

Citation: Miller, M., Anderson, M., Francis, C. A., Kruger, C., Barford, C., Park, J., \& McCown, B. (2013). Critical research needs for successful food systems adaptation to climate change. Journal of Agriculture, Food Systems, and Community Development, 3(4), 161-175. http://dx.doi.org/10.5304/jafscd.2013.034.016

Copyright (C) 2013 by New Leaf Associates, Inc.

\begin{abstract}
There is a growing sense of the fragility of agricultural production in the Global North and South and of increasing risks to food security, as scientific observations confirm significant changes in the Gulf Stream, polar ice, atmospheric $\mathrm{CO}_{2}$, methane release, and other measures of climate change. This sense is heightened as each of us

a,* Corresponding author: Michelle Miller, Associate Director, Center for Integrated Agricultural Systems, University of Wisconsin, 1535 Observatory Drive, Madison, Wisconsin 53706 USA; +1-608-262-7135; mmmille6@wisc.edu

${ }^{\mathrm{b}}$ Molly Anderson, Partridge Chair in Food \& Sustainable Agriculture Systems, College of the Atlantic, 105 Eden Street, Bar Harbor, Maine 04609 USA

${ }^{\mathrm{c}}$ Charles Francis, Professor, Department of Agronomy \& Horticulture, University of Nebraska-Lincoln, Lincoln, Nebraska 68583-0915 USA; and Visiting Professor of Agroecology, Institute of Plant and Soil Science (IPM), P.O. Box 5003, Norwegian University of Life Sciences (UMB), N-1432 Aas, Norway
\end{abstract}

experiences extreme weather, such as the increasing frequency of droughts, floods, unseasonal temperatures, and erratic seasonality. The central research challenge before us is how global, national, regional, and local food systems may adapt to accelerating climate change stresses and uncertainties to ensure the availability, access,

${ }^{\mathrm{d}}$ Chad Kruger, Director, WSU Center for Sustaining Agriculture \& Natural Resources, 1100 North Western Avenue, Wenatchee, Washington 98801 USA

e Carol Barford, Director, Nelson Institute Center for Sustainability and the Global Environment (SAGE), University of Wisconsin-Madison, 1710 University Avenue, Madison, Wisconsin 53726 USA

f Jacob Park, Green Mountain College, with support from the University of Vermont's Research on Adaptation to Climate Change Program. One Brennan Circle, Poultney, Vermont 05764 USA

g Brent H. McCown, Professor Emeritus, Department of Horticulture, University of Wisconsin-Madison, Madison, Wisconsin 53706 USA 
consumption, and stability of healthy food for and by all people. Missing aspects of research fall into two broad categories: the impacts of rapid climate change on the environmental systems supporting food production, and climate change's impact on the predominantly human systems that influence food security. Of particular concern is how different policy and governance mechanisms can support or hinder the collective decision-making needed to promote a swift adaptive response to increase and sustain food security. Human systems research is needed to investigate food system activities beyond production (processing, distribution, consumption, and waste management). It also must consider political, cultural, and regulatory factors that influence behavior and facilitate positive behavioral changes. To accurately envision future scenarios, research is needed to characterize risk comprehensively throughout the food system, assess barriers to and opportunities for changing food systems, and evaluate novel and traditional approaches that may lead to greater food security.

\section{Keywords}

adaptation, climate change, farming, food security, food supply chain, food systems, resilience

\section{Introduction and Rationale}

The central research question we examine in this paper is how global, national, regional, and local food systems may adapt to the stresses and uncertainties of climate change to ensure food security, that is, the availability, access, consumption, and stability of safe and nutritious food for all people. Because food production is critically dependent on local temperatures and precipitation, any change outside the range of current conditions requires farmers to adapt their practices. While the changes may be beneficial for a few farmers, for most farmers the changes will pose major challenges to maintain productivity and manage risk. The ensuing pressure on food systems has the potential to cripple or collapse existing supply chains and further stress vulnerable populations, especially in metropolitan regions where there is a high reliance on distant food production and complex supply chains. Impacts on food supply chains are already rippling out from agricultural production, as well as being felt within each food system activity. Impacts will amplify as rapid changes in other sectors (energy, transportation, trade, etc.) collide with growing needs for food provision.

Responses to climate change need to occur on several levels and in several ways, including crop, farm-level and supply-chain adaptations; privateand public-sector investment at state, national, and international levels; and policies and planning at regional and global levels. Large-scale adaptation strategies include infrastructure investment, waterallocation reform, altered land use, and changes in food trade (Nelson et al., 2010). Leadership, research, and implementation of these strategies are haphazard and fragmented across scales, scope, and timelines. Haphazard leadership results in unstable budget commitments for the work at all levels and types. Planning within and across sectors is in early stages, and agreements on policies have hit numerous political stalemates.

While food systems analysis and synthesis are largely absent from the climate change literature, there is a rapidly growing body of work on agriculture, governance, and community response and implementation that is relevant to food systems. Much of this work is being done outside the United States and is linked to disaster recovery experience from extreme weather events and other natural disasters in developing countries, and thus is highly pertinent to anticipated impacts from climate change.

\section{Impacts of Climate Change and Adaptation Strategies: Production Agriculture}

Food production is the critical first step in the food supply chain, and an area that has received extensive research attention. A subset of this involves research on sustainable agriculture. It is at the intersection of sustainable production agriculture and food systems research that climate adaptation strategies are likely to be found, although much of what has been written to date on climate adaptation and agriculture starts from the broader field of production agriculture.

\section{Status of Current Knowledge}

International research. Many international organizations are weighing in on climate adaptation, 
sometimes with agriculturally specific stories and recommendations embedded in larger reports (Economics of Climate Adaption Working Group [ECA], 2009; Intergovernmental Panel on Climate Change [IPCC], 2007; Investor Group on Climate Change [GCC], Institutional Investors Group on Climate Change [IGCC], \& and Investor Network on Climate Risk [INCR], 2012; Amado, Adams, Coleman, \& Schuchard, 2012; Lim, SpangerSiegfried, Burton, Malone, \& Huq, 2005). These international reports discuss the multiple factors that impact community security (sometimes explicitly including food security), link adaptive capacity with diversity and scale and stress socioecological approaches for systems resilience. Case studies often emphasize developing economies. Global climate change projections and potential impacts on agricultural production are explored in 15 different scenarios for food security through 2050 in a report from the International Food Policy Research Institute (IFPRI) (Nelson et al., 2010). These projections are commonly used in nation-specific reports (for example, Knox, Hurford, Hargreaves, \& Wall, 2012; Nelson et al., 2010).

National research. Many English-speaking countries are heavily invested in national responses to climate change. Extensive reports on climate change and adaptation sometimes include sections that specifically address agriculture. Australia has taken a close look at the community level to determine resilience and adaptability in food systems, employing its Extension Service in the effort (Boon, Millar, Lake, Cottress Cottrell, \& King, 2012; Gero et al., 2013; Reid, 2011). Britain recently published an extensive risk assessment for 11 sectors, including research on the economics of climate resilience in agriculture with a focus on wheat, sugar beets, potatoes, grasslands, livestock, and dairy (Department for Environment, Food and Rural Affairs [DEFRA], 2013; Knox et al., 2012). Canada has committed extensive funds to domestic climate change adaptation work since 2007, including a Federal Adaptation Policy Framework, with funding for various federal agencies to implement the framework. Environment Canada supports extensive work at the provincial level where food systems concerns are most likely to emerge, funding university-based resource hubs for information (Environment Canada [EC], 2013). The U.S. Climate Change Science Program (CCSP) produced an agriculture report, one of a series of 21 "synthesis and assessment products" (CCSP, 2008). The U.S. Department of Agriculture (USDA) then followed up in spring 2013 with draft guidelines for its agencies and programs (USDA, n.d.).

\section{State and regional (subnational) research.}

Generally speaking, regional efforts are focused on community adaptation, with some assessment specific to agricultural production but virtually nothing in a food systems context. North American examples include work on the West Coast, from British Columbia to California; the Midwest, including Ontario, Wisconsin and Nebraska; some Southern states; and the Atlantic seaboard. Some examples follow. The U.S. Pacific Northwest has a considerable history in engaging agriculture and climate change concerns (Barber et al., 2013; Burke \& Ferguson, 2010; Coakley, Jones, Page, \& Dello, 2010; Eigenbrode, Capalbo, Houston, JohnsonMayndard, Kruger, \& Olen, in press; Kruger, Yorgey, \& Stockle, 2011; Stockle et al., 2010). This is in response to the state's agricultural diversity, including the importance of high-value fruit and vegetable production to the economy, uncertainty of the agricultural water supply, the dependence on a winter moisture regime of the cereal-grain production region, and the relative vulnerability of the current regional agricultural system to global market dynamics. Washington and Oregon have completed public stakeholder processes to inform agricultural climate change adaptation policy.

Ontario's Centre for Climate Impacts and Adaptation Resources (OCCIAR) offers an extensive online collection of fact sheets, case studies, tools, and scholarly articles. It sponsors a climate change adaptation community of practice, a study in conjunction with the International Joint Commission on the Great Lakes, a regional adaptation collaborative, a community adaptation initiative, and implementation of the Federal Adaptation Policy Framework at the watershed level (OCCIAR, 2013). The Wisconsin Initiative on Climate Change Impacts (WICCI) produced 
gridded data sets of temperature and precipitation from historical weather records in Wisconsin, and created synthetic future weather data sets for the state based on global climate model output from the Intergovernmental Panel on Climate Change (IPCC, 2007). Early applied research using these data has included modeling studies of plant stress in corn and soybean crops. WICCI is currently downscaling data for the Upper Midwest and Great Lakes regions with the expectation that these projects could establish a standard for a national system of downscaling (WICCI, 2011). Oak Ridge National Laboratory's Community and Regional Resilience Initiative (CARRI) is a program of the congressionally funded Southeast Region Research Initiative. CARRI worked with three partner communities in Mississippi, South Carolina, and Tennessee on community resilience, but without direct reference to food systems (Gunderson, 2009; Moser, 2008). The California Department of Food and Agriculture maintains a website and posts reports on climate change and agricultural adaptation strategies (Jackson et al., 2012). New York is also engaged in climate adaptation governance and research, with some work on agricultural adaptability.

\section{Gaps in Current Knowledge: Production}

Agriculture. Research from around the world has sharpened our understanding of climate change impacts on food production and cast serious doubt on earlier assumptions that climate change will create "winners" (largely industrialized countries in temperate zones) and "losers" (largely poor countries in the tropics). New knowledge of heat, precipitation, and pest management thresholds that will affect yields of major commodity crops, livestock species, and annual and perennial horticultural crops leads to a growing sense of the fragility of agriculture in the Global North and South, and of increasing risks to food security (Beddington et al., 2011; Easterling et al., 2007). Geographic shifts, reduced ranges, and species loss have already been observed for many wild species (Parmesan, 2006; Parmesan \& Yohe, 2003), although analogous effects on crop production may be reduced by adapting planting and harvest dates, irrigation, and crop breeding (Deryng, Sacks, Barford, \&
Ramankutty, 2011; Foley, Ramankutty, Brauman, Cassidy, Gerber, Johnston, \& Zaks, 2011; Lobell, Marshall, Burke Tebaldi, Mastrandrea, Falcon, \& Naylor, 2008; Stockle et al., 2010). Increasing frequency of extreme weather events will add to production risks. Existing research is not sufficient to depict clear adaptation strategies for different crops and regions, to soften the blows that climate change will inevitably deliver to food production.

The scientific literature assessing the impact of climate change on agriculture largely focuses on relatively simple assessments of the impact of changing temperature, precipitation patterns, and $\mathrm{CO}_{2}$ elevation on crop yield (Parry, Rosenzweig, Iglesias, Livermore, \& Fischer, 2004; Parry, Rosenzweig, \& Livermore, 2005; Rosenzweig \& Parry, 1994; Schlenker \& Roberts, 2009), with limited evaluation of adaptive responses by producers (Stockle et al., 2010), minimal integration of climate-induced biotic stressors in yield projections (Coakley, Scherm, \& Chakraborty, 1999), minimal attention to the consequences of extreme weather events (Rupp, Mote, Massey, Rye, Jones, \& Allen, 2012), and virtually no consideration for downstream consequences in the larger food system.

Future research on food production that incorporates the potential impacts of climate-induced biotic stressors and extreme events, especially for protein, fruits, vegetables, and perennial varieties, needs to be a top priority. This research needs to be focused within bioregions, not at a national or state level, and explore how production bioregions link to regional markets (towns, cities, and metropolitan areas where marketing and distribution relationships are likely). Further research linking bioregional production to national and global markets may make sense for certain foods from specific regions. One way to accomplish this may be to conduct research to characterize the vulnerability and adaptive capacity of bioregional food production and regional food supply chains. As we investigate these bottom-up adaptation responses, attention also needs to be paid to the economic risks and the complex place-based socio-ecological realities at the local, regional, and national levels.

A national system for downscaling climate models and synthesizing future weather data to an agriculturally relevant scale would help to localize 
and regionalize food production adaptation.

Researchers and practitioners can look to these data to get a handle on the risks to food crops associated with short- and medium-term variability of temperature and precipitation to food crops by bioregion. This information then has potential to guide research on likely risks and help formulate risk-mitigation tactics for various food cropping systems by production bioregion. This has been done on a limited scale with a few food crops, but remains to be done in a comprehensive manner. Another valuable research area would be development of priority crop varieties with greater resilience traits that are regionally specific.

Bottom-up, producer-level responses for increasing resilience to climate change and extremes are underappreciated by the broader community working on climate adaptation. Strategies for increasing farming system resilience in the face of expected climate fluctuations depend in part on greater spatial and temporal diversity in planting patterns at the crop, field, and farm levels (Francis \& Porter, 2011). At the individual crop level, our current systems depend almost entirely on genetically homogeneous hybrids or varieties, providing uniformity of maturity to ease harvest and of product quality for processing. Yet crops were highly variable traditionally, with individual plants in a population exhibiting different levels of tolerance or resistance to drought, insects, plant pathogens, and the vagaries of weather that were all unpredictable from one season to the next. Organic production systems are not more diverse or resilient per se, but organic systems often employ more variable older varieties with greater population diversity (Wortman et al., in press).

Diversity and resilience start at the field level and are specific to each farm. Alternative farming systems include multiple cropping options such as row and strip intercropping, mixed culture of two or more species, and relay cropping that includes more than one species in the field in the same season. These planting strategies can provide enough diversity to produce yield from at least one of the component crops if another is subject to pests or drought (Francis, 1986). Integrating animals into these cropping systems, including beneficial insects and wildlife, also diversifies the landscape, making it more resilient. Other systems that employ organic or biologically intensive principles reduce input costs and rely on system design to reduce pest pressure. With lower input costs, there is less exposure to risk and numerous other environmental benefits, increasing the economic resilience of the farm (Francis, 2009). Renewed commitment to participatory research on location-specific, diversified production systems, especially in the face of extreme weather, intensified pressure from exotic species, and altered food supply chains is critical to adaptation.

Many trade-offs exist in adaptation strategies for agricultural production, and these need to be better understood. An example of these trade-offs is farm size and creating perennial agricultural landscapes. Small farms are identified as more vulnerable to climate change due to the tight profit margins that hinder their ability to respond to risk (DEFRA, 2013). A countervailing factor is that small-farm decisions tend to be short-term, so there is a high level of farmer adaptive capacity (DEFRA, 2013). Adaptive capacity may be reduced with crops or animals with longer life spans, yet perennial crops hold promise as adaptive responses to extreme weather. Perennial crops are suited to marginal agricultural land, including highly erodible land, because of their capacity to hold soil in place during extreme rainfall events. Some perennials thrive during drought by drawing moisture through deep roots (Hirsch \& Miller, 2008). The U.S. Department of Agriculture Natural Resources Conservation Service (USDA-NRCS) notes that climate change exacerbates threats to highly erodible lands (HEL), soil quality, and stream temperatures, and increases pressure from invasive species (Driftless Area Initiative [DAI], 2013). How do we support increased system resilience by moving perennial cropping systems in the direction of forest-like ecological function, with intercropping, beneficial insect habitat, increased "edge effect," and other diversification strategies? How many of these strategies are amenable to small farms with lower profit margins and less ability to set aside land for nonproductive purposes? What innovations could be employed at other points in the food supply chain that would more equitably spread the risk between farmers and consumers? 
Climate Change Impacts and Adaptation Strategies: Food System Activities Beyond Production

The food supply chain starts with production, but it doesn't end there. Food processing, distribution, retailing, and waste management will also feel the impact of extreme weather due to climate change.

\section{Status of Current Knowledge}

Climate change will affect the entire food system; its impacts are not limited to agricultural production. For example, sea-level rise and extreme weather events may have disastrous consequences for key points in food distribution networks, as exemplified by the Interstate 5 flooding in the state of Washington in January 2009 that restricted food distribution to the more than 3 million residents of the Greater Seattle area. In the arena of food consumption, the spread of pathogens toward the poles and market shifts to "warm food chains" instead of "cold food chains" due to rising costs of fossil fuels and growing awareness of greenhouse gas emissions will affect food safety risks. Other social changes will have food system impacts as well: for example, growing public concerns about emission of greenhouse gases have the potential to affect every food system activity given the heavy reliance of the entire food system on fossil fuels. Alternative energy sources will be needed to produce and distribute food, yet very little investment has been made in alternative energy to date, and the costs of this lack of investment have not been quantified.

In contrast to the extensive work now being done on the effects of climate change on agricultural production and the potential for adaptation, there are fewer studies on impacts and adaptation strategies in other food system activities (Ingram, 2011; Vermeulen, Campbell, \& Ingram, 2012).

Some of the best early work was done in the United Kingdom by Garnett (2008) and at Oxford University's Environmental Change Institute. In addition, CGIAR's Research Program on Climate Change, Agriculture, and Food Security (CCAFS) was established in 2010 as a 10-year research initiative to examine interconnections in developing countries between food production and consumption, as affected by climate change (CCAFS, 2010).
Industry has jumped into the lacuna of academic work on food system impacts of climate change because business sustainability and viability depend on having good predictions of the magnitude and severity of climate change risks and responding appropriately. Industry has been proactive in seeking adaptive strategies and taking action. For example, the World Economic Forum's 2013 report on global risk emphasized climate change as the third most serious global risk overall, trumped only by severe income disparities and chronic fiscal imbalances of governments (Howell, 2013). The Carbon Disclosure Project (CDP) is based on the premise that business advantages will accrue from public disclosure of climate change impacts and that businesses must share information and innovation about carbon management; its corporate members include the Coca-Cola Company, Walmart, PepsiCo, Nestle, and Unilever. In its most recent survey, 70 percent of the 2,415 responding organizations reported that current or future risks from climate change have the potential to significantly affect their business or revenue. Respondents indicated that more than half of supply chain risks are due to drought and precipitation extremes that are already affecting their operations (Accenture, 2013). Unilever stands out for proactive greenhouse gas emissions reductions; according to CDP data, it surpassed all other British industries in 2010 in how it was dealing with climate change (Carrell, 2010).

\section{Gaps in Current Knowledge: Food System Activities Beyond Production}

Food is increasingly produced and traded in a global market reliant on cheap transportation, cheap labor, and predictable weather patterns. But there is increasing evidence that our existing infrastructure is highly vulnerable to climate change. For instance, the Washington State Department of Transportation (WDOT) has identified serious vulnerabilities to extreme weather events in the transportation system, including highways, ports, railways and bridges (WSDOT, 2012). Food distribution creates bottlenecks in food supply chains. Greg Reid, Australian climate advisor with New South Wales Trade and Investment, notes that urban centers reliant on distribution are often the 
most vulnerable to disruption by climate extremes. $\mathrm{He}$ asserts that communities with high social and natural capital but low distributional capital tend to be more self-sufficient and resilient to short-term impacts, but vulnerable to long-term impacts (drought, sea level rise, etc.) (G. Reid, personal communication, May 14, 2013). High distributional capital also can indicate accelerated depletion of natural capital (such as ground water, or arable land lost to urban development). Countries, regions, metropolitan areas, or communities dependent on imports of distributed foods are vulnerable to price fluctuations and consequent destabilization of their social capital (G. Reid, personal communication, May 14, 2013). Cities are usually dependent on freight transportation, and those that serve as distributional hubs are perhaps the most vulnerable. In addition, major metropolitan areas are grappling already with metropolitan core problems (e.g., congestion and double parking), environmental impacts, and dilemmas associated with transportation hubs (Jaffee, 2013). In North America, the primary food logistical hubs are Calgary, Los Angeles, Atlanta, Chicago, Toronto, and northern New Jersey/eastern Pennsylvania, with smaller hubs often situated within 250 miles $(400 \mathrm{~km})$ of more populous areas (MWPVL International, 2013). How is the current food distribution system vulnerable to climate change, and what changes are likely as production patterns shift? How can food be moved smoothly and equitably from where it is grown to where it will be consumed without generating environmental impacts and the problems now associated with logistical hubs? How can we address the foodwaste problem in a way that closes the cycle back to food production and perhaps contributes to alternatives to fossil fuel, rather than perpetuates imbalance?

Efficiencies in the food system further increase systems imbalance. In the U.S., the trend toward big-box groceries and small specialty stores has resulted in the demise of independent, midscale regional and local supermarkets, trucking companies, and warehouses, thereby reducing diversity, eliminating redundancies, and lessening resilience (Zurayk, 2012). The supermarket industry is mature, highly competitive, and rapidly consolidating (The Reinvestment Fund, 2011). Between 1990 and 2010, almost 43 percent of the retail grocery market share shifted from small and midscale supermarkets to big-box stores (MWPVL International, 2013). The top 75 food retailers in North America account for almost 50,000 stores, 533 distribution centers, and US $\$ 891$ billion in sales (MWPVL International, 2013). In 2010, the top 10 retailers took 68 percent of sales, even though they accounted for only 35 percent of the number of stores (The Reinvestment Fund, 2011). A primary way large retailers realize efficiencies of scale is through self-distribution and just-in-time supplies, which then increase dependence on largescale efficiencies and hinder small and midscale farms and stores from participating in modest-scale food commerce (Bittner, Day-Farnsworth, Miller, Kozub, \& Gollnik, 2011; Nelson, Miller, Morales, \& Zeitlow, 2013). Yet redundancy is a key way to build system resilience (Clancy \& Ruhf, 2010). How do these trends impact food system resilience? In a food system dominated by market forces that have very small profit margins for many actors, how can redundancy be encouraged when it primarily benefits the public good? If diversity is a key component of environmental resilience, then how much and what kinds of business diversity contribute to economic and social resilience?

Hamlet (2011) recommends that consideration for the impact of climate change become standard in the design and maintenance of the transportation infrastructure necessary for conveying goods to and within regional markets. Regional food systems, where food is grown closer to market, complement national and global food markets, and add resilience to our food system. As a diversification strategy, regionalization has the potential to maintain food security if food system variables are upset through, for instance, extreme weather, rapid increases in fuel prices, or drastic changes in institutional support, such as water subsidies or farm bill programs (Neff, Parker, Kirschenmann, Tinch, $\&$ Lawrence, 2011). How can we craft freight logistics to create regional transportation efficiencies for food? What infrastructure will be needed as regional food systems develop? When states are primarily responsible for maintaining transportation infrastructure and many do not have funds to 
provide for the most basic public services, where will extra funds for maintaining transportation infrastructure be found?

A new generation of food technology and business ventures has the potential to transform and diversify both the local and national food system landscape. Emerging sustainable food enterprises are likely to have more positive, climate-resilient outcomes. According to Slow Money, a sustainable food finance and entrepreneurship network, "more than [US] \$30 million has been invested in over 220 small food enterprises since 2010" (Slow Money, "Investment Summary," para. 1). However, it is not clear if the much greater amount that is being invested in more traditional food business start-ups is complementing or undermining these sustainable food entrepreneurship efforts. In 2012, for instance, private-equity and venture-capital firms invested US $\$ 350$ million in a wide range of food-related business ventures, representing a more than sevenfold increase from the amount invested in 2008 (Wortham \& Miller, 2013). How can the private sector be encouraged to ensure food system resilience in the face of climate change in all new businesses, and to retrofit existing businesses for this purpose?

Although studies of supply chains demonstrate many of the vulnerabilities of food systems and suggest how to address these to minimize risk to food industries, they do not deal as well with impacts on public goods, including food security for people who cannot afford to purchase the products of global food industries. Research gaps below are generally related to public goods, including sound governance.

\section{Research Gaps Relevant to the Entire Food System}

Many of the unknowns related to food system impacts and adaptation to climate change will affect the entire food system. For example, the heavy reliance of all food system activities on fossil fuels was mentioned above. How can a massive transition to energy conservation and renewable energy be effected throughout the food system, with the least possible social disruption?

As we better understand risks at the farm level, we can research adaptive responses from both the public and private sectors that spread food production risks throughout supply chains so that farmers and people who are food-insecure do not bear the brunt of rapid change and crippled supply chains. Of particular concern is how different governance mechanisms can support or hinder the collective decision-making needed to promote adaptive responses to increase and sustain food security. Governance concerns extend all the way to the research team composition itself: developing adaptive strategies will require coordinated contributions from social, ecological, systems, climate, and agronomic scientists, as well as farmers, other business stakeholders, and those working in the public interest (such as the government and nongovernmental organizations).

What are the most effective spatial, economic, and political scales at which to adapt food systems to climate change? What is the critical path to adaptation? National and multinational governance mechanisms tend to be fragmented and insufficient. Comparative research looking at Canadian and American subnational and private-sector response suggests that this "middle tier" has the greatest potential to address the complexities of these "wicked" problems (Burke \& Ferguson, 2010; Urwin \& Jordon, 2008). Programs at the midscale tend to be more comprehensive in their ability to involve stakeholders in a productive way. Effective stakeholder engagement and participation are key concerns, since resilience at the community level is a foundation for adaptation (Larson, 2010; Leggewie \& Welzer, 2010; Reid 2011). The University of British Columbia's Institute of Environment, Resources, and Sustainability work related to climate change emphasizes participatory capacity-building (Bizikova, Burch, Robinson, Shaw, \& Sheppard, 2009; Shaw et al., 2009; Sheppard et al., 2009). There is an extensive discussion on measuring vulnerability, adaptive capacity, and human systems resilience during times of accelerated change; looking at the structure of any given sector and the organizations involved; and raising the importance of discourses and narratives (Berman, Quinn, \& Paavola, 2012; Brockhaus, Djoudi, \& Kambire, 2012; Gupta et al., 2010; IPCC Core Writing Team, Pachauri, \& 
Reisinger, 2007; Ogalleh, Vogl, \& Hauser, 2013). Of particular interest are the use of Bronfenbrenner's bio-ecological systems theory (Boon et al., 2012), the Adaptive Capacity Wheel (Gupta et al., 2010), and participatory back-casting (Robinson, Burch, Talwar, O’Shay, \& Walsh, 2011). Still, community adaptation requires centralized drivers such as national government agencies to assess risk, modify infrastructure, and facilitate fundamental systems change. How do we effectively engage public and private resources in ongoing civic discourse and action on adaptation? What does our methodological tool kit look like, and what is it missing?

Strategic grain reserves are an important food system adaptation to climate variability at national and global levels. Large modern grain reserves were first established in the 1970s in response to drought and famine in the Sahel region of Africa, concurrent with a global grain shortage and high prices (Lynton-Evans, 1997). Since their establishment grain reserves have also been used to meet other economic and political goals (e.g., commodity price manipulation), and in this sense they are analogous to the agricultural sector in general. The Food and Agriculture Organization of the United Nations (FAO) considers several different factors in its guidelines for grain-reserve operation: size, location, proportion of physical stock vs. cash reserve, and clarity in the intention of the reserve, i.e., whether it is intended as a buffer in normal market operations, or as a separate reserve in the case of food scarcity (Lynton-Evans, 1997). These considerations are treated in a formal systems analysis by Eaton (1980), which optimizes grain reserves in a multi-objective environment (farmers' objectives, consumers' objectives, and system constraints). It is noteworthy that Eaton used water systems analysis techniques, another sector with stocks (reservoirs) and flows subject to environmental influence. Grain storage is a relatively simple example of the importance of strategic storage in the broader food system, as highlighted by recent studies of the "just-in-time" food supply and related vulnerability of urban populations (Cockrall-King, 2012; FAO, 2000).

Basic research and monitoring are needed at the local and regional levels in order to quantify the relevant stocks and flows of these nested components of complex food systems. In turn, these data can be used to parameterize food systems models, facilitate hypothesis testing, and inform future policies.

Climate change is likely to exacerbate existing conflicts over water and land, as production and distribution become less predictable and areas suitable for agricultural production shrink. Attempts to grow more biofuel crops will only increase the pressure on food supply and prices, which is likely to put food out of the reach of more consumers. Environmental refugees from areas that are flooded or affected by weather disasters will add to that pressure, because they will be dependent on food aid; political instability is a likely scenario (Leggewie \&Welzer, 2010). How can food system governance be implemented to make decisions about the allocation of land, water, and other resources among competing interests, so that the basic needs and human rights of the most vulnerable people take precedence over financial benefits to wealthier and more politically powerful people? Social sciences can help provide insight into these fundamental questions about power and dominance within and between societies (Barnes et al., 2013).

\section{Conclusion}

Climate change will entail multiple exposures to overlapping and interacting stressors on our food system, inevitable cross-scale trade-offs, drivers, and feedback mechanisms in the food system. Clearer scenarios are needed for how costs and benefits can be distributed more equitably, and how risks to those most vulnerable to stressors can be reduced (Gregory, Ingram, \& Brklacich, 2005; Ingram, 2011; Vermeulen et al., 2012). A comprehensive assessment of the points at which food systems are most vulnerable to climate change, and the impacts of this vulnerability on food security, is needed (Benedikter, Läderach, Eitzinger, Cook, Quiroga, Pantoja, \& Bruni, 2013).

Current contributions to food systems adaptation research are relatively few in number and not coordinated. While information on agriculture is growing rapidly, there is less information on growing nutritionally dense food (proteins, fruits, and 
vegetables, as opposed to cereals, crops for biofuels, fiber, etc.) and ensuring that this food reaches the most vulnerable people, who are largely unable to influence market forces. Discussion about the resilience of food provisioning is largely absent. Is this because most of the work on climate change is conducted at the national and community scales, in isolation, rather than on multiple, integrated scales? Transdisciplinary research can help sort out the critical tasks at hand.

In understanding the impact of climate change on food systems, we seek to optimize resilience. We can do this by moving away from developing simple food supply chains to developing food supply webs where interconnection is enhanced, unpredictable, multimodal, and complex. We may also consider what efficiencies can be undone or are likely crumble, thus creating "wiggle room" in existing national and global systems, to allow for systems change. In optimizing resilience, setting up better ways to capture learning and transformability is also important (Folke, Carpenter, Walker, Scheffer, Chapin, \& Rockström, 2010; Walker \& Salt, 2012); that is, resilience is not about resisting change, but about anticipating change and using it to our advantage.

To envision scenarios forward, research on adaptation needs to characterize risk comprehensively in specific food supply chains and webs, quantify current barriers to and identify opportunities for creating more resilience in our food system, and demonstrate how both novel and traditional approaches can lead to greater food security.

\section{Acknowledgements}

The authors acknowledge the coordination of this publication effort by Joanna Friesner, National Network Coordinator for the Inter-institutional Network for Food, Agriculture and Sustainability (INFAS), of which M. Miller, M. Anderson, C. Francis, and C. Kruger are institutional members. INFAS is supported by a grant from the W. K. Kellogg Foundation.

\section{References}

Accenture. (2013). Reducing risk and driving business value: Carbon Disclosure Project supply chain report 2012-13.
New York and London: Carbon Disclosure Project. Retrieved from http://www.cdproject.net

Amado, J.-C., Adams, P., Coleman, H., \& Schuchard, R. (2012). PREP V alue chain climate resilience: A guide to managing climate impacts in companies and communities. Montréal: Acclimatise; Boston: Oxfam America; and San Francisco: BSR. Retrieved from the Oxfam America website: http://www.oxfamamerica.org/ publications/prep-value-chain-climate-resilience

Barber, M. E., Adam, J. C., Brady, M. P., Chinnayakanahalli, K. J., Rajagopalan, K., Dinesh, S., ... Yorgey, G. G. (2013). Global change implications on long-term water supply and demand forecasts in the Columbia River Basin. In H. Bjornlund \& C. A. Brebbia (Eds.), Sustainable irrigation and drainage IV: Management, technologies and policies (pp. 77-86). Southampton, UK: WIT Press.

Barnes, J., Dove, M., Lahsen, M., Mathews, A., McElwee, P., McIntosh, R.,... Yager, K. (2013). Contribution of anthropology to the study of climate change. Nature Climate Change, 3, 541-544. http://dx.doi.org/10.1038/nclimate1775

Beddington, J., Asaduzzaman, M., Fernandez, A., Clark, M., Guillou, M., Jahn, M.,... Wakhungu, J. (2011). Achieving food security in the face of climate change: Summary for policy makers from the Commission on Sustainable Agriculture and Climate Change.

Copenhagen: CGIAR Research Program on Climate Change, Agriculture and Food Security (CCAFS). Retrieved from http://www.ccafs.cgiar.org/commission

Benedikter, A., Läderach, P., Eitzinger, A., Cook, S., Quiroga, A., Pantoja, A., \& Bruni, M. (2013). Global climate change and food supply chains: Policies for collective adaptation (Policy Brief No. 11). Retrieved from International Center for Tropical Agriculture (CIAT) website: http://www.ciat.cgiar.org

Berman, R., Quinn, C., \& Paavola, J. (2012). The role of institutions in the transformation of coping capacity to sustainable adaptive capacity. Environmental Development, 2, 86-100. http://dx.doi.org/10.1016/j.envdev.2012.03.017

Bittner, J., Day-Farnsworth, L., Miller, M., Kozub, R., \& Gollnik, B. (2011). Maximizing freight movements in local food markets. Retrieved from the National Center for Freight \& Infrastructure Research and Education, University of Wisconsin-Madison, website: http://www.wistrans.org/cfire/2011/ $\underline{10 / \text { final-report- } 0423 /}$ 
Bizikova, L., Burch, S., Robinson, J., Shaw, A., \& Sheppard, S. (2009). Utilizing participatory scenario-based approaches to design proactive responses to climate change in the face of uncertainties. In G. Gramelsberger \& J. Fleichter (Eds.), Climate change and policy: The calculability of climate change and the challenge of uncertainty (pp. 171190). Heidelberg, Berlin, New York, Tokyo: Springer.

Boon, H., Millar, J., Lake, D., Cottrell, A., \& King, D. (2012). Recovery from disaster: Resilience, adaptability and perceptions of climate change. Retrieved from the National Climate Change Adaptation Research Facility website: http://www.nccarf.edu.au/ publications/recovery-disaster-resilienceadaptability-climate-change

Brockhaus, M., Djoudi, H., \& Kambire, H. (2012). Multi-level governance and adaptive capacity in West Africa. International Journal of the Commons, 6(2), 200-232. Retrieved from http://www.thecommons journal.org/index.php/ijc/issue/view/22

Burke, B., \& Ferguson, M. (2010). Going alone or moving together: Canadian and American middle tier strategies on climate change. The Journal of Federalism, 40(3), 436-459. http://dx.doi.org/10.1093/publius/pjq012

Carrell, S. (2010, June 29). Unilever tops climate change index with 'superb' track record. The Guardian. Retrieved from http://www.guardian.co.uk/ environment/2010/jun/29/unilever-climatechange-index

Clancy, K. \& Ruhf, K. (2010). Is local enough? Some arguments for regional food systems. Choices: The Magazine of Food, Farm and Resource Issues, 25(1). Retrieved from http://www.choicesmagazine.org/ magazine/pdf/article 114.pdf

Climate Change, Agriculture, and Food Security, Research Program on. [CCAFS]. (2011). CCAFS annual report 2010: World's largest coalition of researchers on climate change, agriculture and food security gears up. Copenhagen, Denmark: CCAFS. Retrieved from http://cgspace.cgiar.org/handle/10568/10257

Climate Change Science Program [CCSP]. (2008). The effects of climate change on agriculture, land resources, water resources, and biodiversity. Washington, D.C.: U.S. Environmental Protection Agency. Retrieved from http://library.globalchange.gov/products/ assessments /2004-2009-synthesis-and-assessmentproducts/sap-3-4-the-effects-of-climate-change-on- agriculture-land-resources-water-resources-andbiodiversity

Coakley, S. M., Jones, G. V., Page, S. \& Dello, K. D. (2010). Climate change and agriculture in Oregon. In K. D. Dello \& P. W. Mote (Eds.), Oregon climate assessment report (pp. 153-174). Corvallis, Oregon: College of Oceanic and Atmospheric Sciences, Oregon State University. Retrieved from http://occri.net/wp-content/uploads/2011/04/ chapter4ocar.pdf

Coakley, S. M., Scherm, H., \& Chakraborty, S. (1999). Climate change and plant disease management. Annual Review of Phytopathology, 37, 399-426. http://dx.doi.org/10.1146/annurev.phyto.37.1.399

Cockrall-King, J. (2012). Food and the city: Urban agriculture and the new food revolution. Amherst, New York: Prometheus Books.

Department for Environment, Food and Rural Affairs [DEFRA]. (2013). Economics of climate resilience: Agriculture and forestry theme: Agriculture. London: Frontier Economics Ltd. and Ibaris LLP. Retrieved from http://weadapt.org/knowledge-base/ economics-of-adaptation/ecr-agriculture

Deryng, D., Sacks, W. J., Barford, C. C., \& Ramankutty, N. (2011). Simulating the effects of climate and agricultural management practices on global crop yield. Global Biogeochemical Cycles, 25(2). http://dx.doi.org/10.1029/2009GB003765

Driftless Area Initiative [DAI]. (2013). Driftless Area Initiative projects. Retrieved from http://www.driftlessareainitiative.org/projects.cfm

Eaton, D. J. (1980). A systems analysis of grain reserves (Technical Bulletin 1611). Washington, D.C.: U.S. Department of Agriculture.

Economics of Climate Adaption Working Group [ECA]. (2009). Shaping climate-resilient development: A framework for decision-making. Retrieved from the European Commission website: http://ec.europa.eu/ development/icenter/repository/ECA Shaping Climate Resilent Development.pdf

Easterling, W.E., Aggarwal, P. K., Batima, P., Brander, K. M., Erda, L. Howden, S.M. ... Tubiello, F.N. (2007). Food, fibre and forest products. In M. L. Parry, O. F. Canziani, J. P. Palutikof, P. J. van der Linden \& C. E. Hanson (Eds.), Climate change 2007: Impacts, adaptation and vulnerability (pp. 273-313). Cambridge, UK: Cambridge University Press. Retrieved from http://www.ipcc.ch/publications and data/ar4/wg2/en/ch5.html 
Eigenbrode, S., Capalbo, S., Houston, L., JohnsonMaynard, J., Kruger, C. E., \& Olen, B. (in press). Agriculture. In P. Mote \& A. Snover (Eds.), Northwest climate assessment report. Washington, D.C.: Island Press.

Environment Canada [EC]. (2013). Canada's ongoing commitment to climate change adaptation. http://ec.gc.ca/default.asp?lang=En\&n=2D1D6F A7-1\&news $=$ B67A7995-A1CA-4DE3-89D2E4E3C0E24BFB

Foley, J. A., Ramankutty, N., Brauman, K. A., Cassidy, E. S., Gerber, J. S., Johnston, M., ... Zaks, D. P. M. (2011). Solutions for a cultivated planet. Nature, 478(7369), 337-342. http://www.nature.com/ nature/journal/v478/n7369/abs/nature10452.html \#supplementaryinformation

Folke, C., Carpenter, S. R., Walker, B., Scheffer, M., Chapin, T., \& Rockström, J. (2010). Resilience thinking: Integrating resilience, adaptability and transformability. Ecology and Society, 15(4), Article 20. http://www.ecologyandsociety.org/vol15/iss4/ art20/

Food and Agriculture Organization of the United Nations [FAO]. (2000). Food for the cities. food supply and distribution policies to reduce urban food insecurity. Rome: Author. Retrieved from http://www.fao. org/DOCREP/003/X8296E/ X8296E00.HTM

Francis, C. A. (1986). Multiple cropping systems. New York: Macmillan Publishers.

Francis, C. (Ed.). (2009). Organic farming: The ecological system. Agronomy Monograph 54, American Society of Agronomy, Madison, Wisconsin.

Francis, C. A., \& Porter, P. (2011). Ecology in sustainable agriculture practices and systems. Critical Reviews in Plant Science, 30(1-2), 64-73. http://dx.doi.org/10.1080/07352689.2011.554353

Garnett, T. (2008). Cooking up a storm: Food, greenhouse gas emissions and our changing climate. Food Climate Research Network. Retrieved from http://www.fcrn.org.uk/sites/default/files/ CuaS web.pdf

Gero, A., Fletcher, S., Rumsey, M., Thiessen, J., Kuruppu, N., Buchan, J., ...Willetts, J. (2013). Disaster response and climate change in the Pacific. National Climate Change Adaptation Research Facility. Retrieved from http://www.nccarf. edu.au/publications/disaster-response-climatechange-pacific
Gregory, P. J., Ingram, J. S. I., \&Brklacich, M. (2005). Climate change and food security. Philosophical Transactions of the Royal Society B, 360(1463), 21392148. http://dx.doi.org/10.1098/rstb.2005.1745

Gunderson, L. (2009). Comparing ecological and human community resilience (CARRI Research Report 5). Oakridge National Laboratory. Retrieved from http://www.resilientus.org/publications/researchreports/

Gupta, J., Termeer, C., Klostermann, J., Meijerink, S., van der Brink, M., Jong, P., Nooteboom, S., \& Bergsma, E. (2010). The Adaptive Capacity Wheel: A method to assess the inherent characteristics of institutions to enable the adaptive capacity of society. Environmental Science and Policy, 13(6), 459471. http://dx.doi.org/10.1016/i.envsci.2010.05.006

Hamlet, A. F. (2011). Impacts of climate variability and climate change on transportation systems and infrastructure in the Pacific Northwest. University of Washington Climate Impacts Group. Retrieved from http://cses.washington.edu/cig/outreach/ newsletterfiles/hamlettransportation.pdf

Hirsch, R. M., \& Miller, M. M. (2008). Progressive planning to address multiple resource concerns: Integrated pest management in Wisconsin orchards. Journal of Soil and Water Conservation, 63(2), 40A-43A. http://dx.doi.org/10.2489/63.2.40A

Howell, L. (Editor in Chief). (2013). Global risks 2013, eighth edition. World Economic Forum. Available at http://reports.weforum.org/global-risks-2013/

Ingram, J. (2011). A food systems approach to researching food security and its interactions with global environmental change. Food Security, 3(4), 417-431 http://dx.doi.org/10.1007/s12571-0110149-9

Intergovernmental Panel on Climate Change [PCC] Core Writing Team, Pachauri, R. K., \& Reisinger, A. (2007). Fourth assessment report for the Intergovernmental Panel on Climate Change. Cambridge, UK, and New York: Cambridge University Press.

Investor Group on Climate Change [IGCC], Institutional Investors Group on Climate Change [IIGCC], \& and Investor Network on Climate Risk [INCR]. (2012). Institutional investors' expectations of corporate climate risk management. Retrieved from the Ceres website: http://www.ceres.org/incr 
Jackson, L., Haden, V. R., Hollander, A. D., Lee, H., Lubell, M., Mehta, V. K.,...Wheeler, S. M. (2012). Adaptation strategies for agricultural sustainability in Yolo County, California (California Energy Commission Publication No. CEC-500-2012-032). Retrieved from http://www.energy.ca.gov

Jaffe, E. (2013, May 22). The forgotten urban transportation problem we should be trying to fix [Web log post]. The Atlantic Cities. Retrieved from http://www.theatlanticcities.com/jobs-andeconomy/2013/05/forgotten-urbantransportation-problem-we-should-be-tryingfix $/ 5672 /$

Knox, J. W., Hurford, A., Hargreaves, L. \& Wall, E. (2012). Climate Change Risk Assessment for the Agriculture Sector (DEFRA Project Code GA0204). London: Department for Environment, Food and Rural Affairs (DEFRA).

Kruger, C., Yorgey, G., \& Stockle, C. (2011). Climate change and agriculture in the Pacific Northwest. Rural Connections, 5(2), 51-54. Retrieved from http://issuu.com/uaes/docs/rural_connections june11/3? e=1049256/3856371

Larson, S., (2010). Understanding barriers to social adaptation: Are we targeting the right concerns? Architectural Science Review, 53(1), 51-58. http://dx.doi.org/10.3763/asre.2009.0103

Leggewie, C., \& Welzer, H. (2010). Another "Great Transformation"? Social and cultural consequences of climate change. Journal of Renewable and Sustainable Energy, 2(3), 031009. http://dx.doi.org/10.1063/1.3384314

Lim, B., Spanger-Siegfried, E. (Eds.), Burton, I., Malone, E. L., \& Huq, S. (Co-authors). (2005). Adaptation policy framework for climate change: Developing strategies, policies and measures. Cambridge, UK: Cambridge University Press.

Lobell, D. B., Burke, M. B., Tebaldi, C., Mastrandrea, M. D., Falcon, W. P., \& Naylor, R. L. (2008). Prioritizing climate change adaptation needs for food security in 2030. Science, 319(5863), 607-610. http://dx.doi.org/10.1126/science.1152339

Lynton-Evans, J. (1997). Strategic grain reserves - guidelines for their establishment, management and operation (FAO Agricultural Services Bulletin 126). Rome: Food and Agriculture Organization of the United Nations
(FAO). Retrieved from http://www.fao.org/ docrep/W4979E/W4979E00.htm

Moser, S. C. (2008). Resilience in the face of global environmental change (Community and Regional Resilience Initiative Research Report 2), Oak Ridge, Tennessee: Oak Ridge National Laboratory. Retrieved from the Community \& Regional Resilience Institute website: http://www.resilientus.org/

MWPVL International. (2013). The grocery distribution center network in North America. Retrieved from http://www.mwpvl.com/html/grocery distribution network.html

Neff, R. A., Parker, C. L., Kirschenmann, F. L., Tinch, J., \& Lawrence, R. S. (2011). Peak oil, food systems, and public health. American Journal of Public Health, 101(9) 1587-1597 http://dx.doi.org/10.2105/AJPH.2011.300123

Nelson, D., Miller, M., Morales, A., \& Zeitlow, B. (2013). Achieving scale strategically: Understanding freight flows in regional food supply chains. National Center for Freight \& Infrastructure Research \& Education. University of Wisconsin-Madison. Retrieved from http://www.wistrans.org/cfire/documents/ FR CFIRE0517.2.pdf

Nelson, G. C., Rosegrant, M. W., Palazzo, A., Gray, I., Ingersoll, C., Robertson, R.,...You, L. (2010). Food security, farming, and climate change to 2050: Scenarios, results, policy options. Washington, D.C.: International Food Policy Research Institute (IFPRI). http://dx.doi.org/10.2499/9780896291867

Ogalleh, S. A., Vogl, C., \& Hauser, M. (2013). Reading from farmers' scripts: Local perceptions on climate variability and adaptations in Laikipia, Rift Valley, Kenya. Journal of Agriculture, Food Systems, and Community Development, 3(2), 77-94. http://dx.doi.org/10.5304/jafscd.2013.032.004

Ontario Center for Climate Impacts and Adaptation Resources [OCCIAR]. (2013). Welcome to OCCIAR. Retrieved from http://www.climateontario.ca/

Parmesan, C. (2006). Ecological and evolutionary responses to recent climate change. Annual Review of Ecology, Evolution, and Systematics, 37, 637-669. http://dx.doi.org/10.1146/annurev.ecolsys.37.0913 $\underline{05.110100}$

Parmesan, C., \& Yohe, G. (2003). A globally coherent fingerprint of climate change impacts across natural systems. Nature 421, 37-42

http://dx.doi.org/10.1038/nature01286 
Parry, M. L., Rosenzweig, C., Iglesias, A., Livermore, M., \& Fischer, G. (2004). Effects of climate change on global food production under SRES emissions and socio-economic scenarios. Global Environmental Change, 14(1), 53-67. http://dx.doi.org/10.1016/i.gloenvcha.2003.10.008

Parry, M., Rosenzweig, C., \& Livermore, M. (2005). Climate change, global food supply and risk of hunger. Philosophical Transactions of the Royal Society, Series B, 360(1463), 2125-2138. http://dx.doi.org/10.1098/rstb.2005.1751

Reid, G. (2011). Building a coordinated approach to Climate Change extension. Extension Farming Systems Journal, 7(2), 38-40. Retrieved from http://www.csu.edu.au/faculty/science/saws/ afbm/archive/efs-journal

Reinvestment Fund, The. (2011). Understanding the grocery industry. Retrieved from http://www.cdfifund.gov/what_we_do/resources/ Understanding $\% 20$ Grocery $\% 20$ Industry for $\% 20 \mathrm{fu}$ nd 102411.pdf

Robinson, J., Burch, S., Talwar, S., O’Shay, M., \& Walsh, M. (2011). Envisioning sustainability: Recent progress in the use of participatory backcasting approaches for sustainability research. Technological Forecasting and Social Change, 78(5), 756-768. http://dx.doi.org/10.1016/j.techfore.2010.12.006

Rozenzweig, C., \& Parry, M. L. (1994). Potential impact of climate change on world food supply. Nature, 367(6459), 133-138. http://dx.doi.org/10.1038/367133a0

Rupp, D. E., Mote, P. W., Massey, N., Rye, C. J., Jones, R., \& Allen, M. R. (2012). Did human influence on climate make the 2011 Texas drought more probable? In T. C. Peterson, P. A. Stott, S. Herring (Eds.), Explaining extreme events of 2011 from a climate perspective (pp. 1052-1054). Bulletin of the American Meteorological Society, 93(7), 1041-1067, http://dx.doi.org/10.1175/BAMS-D-12-00021.1

Schlenker, W., \& Roberts, M. J. (2009). Nonlinear temperature effects indicate severe damages to U.S. crop yields under climate change. Proceedings of the National Academy of Sciences of the United States of America,106(37) 15594-15598. http://dx.doi.org/10.1073/pnas.0906865106

Shaw, A., Sheppard, S., Burch, S., Flanders, D., Wiek, A., Carmichael, J.,...Cohen, S. (2009). Making local futures tangible — Synthesizing, downscaling, and visualizing climate change scenarios for participatory capacity building. Global Environmental Change, 19(4), 447-463

http://dx.doi.org/10.1016/j.gloenvcha.2009.04.002

Sheppard, S. R. J., Shaw, A., Flanders, D., Burch, S., Wiek, A., Carmichael, J., ... Cohen, S. (2009). Future visioning of local climate change: A framework for community engagement and planning with scenarios and visualization. Futures, 43(4), 400-412. http://dx.doi.org/10.1016/j.futures.2011.01.009

Slow Money. (n.d.). Investment summary. Retrieved 8/26/13 from http://slowmoney.org/invest

Stockle, C. O., Nelson, R. L., Higgins, S., Brunner, J., Grove, G., Boydston, R., ... Kruger, C. (2010). Assessment of climate change impact on eastern Washington agriculture. Climatic Change 102(1-2), 77-102. http://dx.doi.org/10.1007/s10584-0109851-4

Urwin, K., \& Jordan, A. (2008). Does public policy support or undermine climate change adaptation? Exploring policy interplay across different scales of governance. Global Environmental Change, 18(1), 180-191.

http://dx.doi.org/10.1016/i.gloenvcha.2007.08.002

U.S. Department of Agriculture [USDA]. (n.d.). USDA Climate Change Adaptation Plan. Retrieved from http://www.usda.gov/oce/climate change/adaptat ion/adaptation_plan.htm

Vermeulen, S. J., Campbell, B. M., \& Ingram, J. S. I. (2012). Climate change and food systems. Annual Review of Environment and Resources, 37, 195-222 http://dx.doi.org/10.1146/annurev-environ020411-130608

Walker, B., \& Salt, D. (2012). Resilience practice: Building capacity to absorb disturbance and maintain function. Washington, D.C.: Island Press.

Washington Department of Transportation [WDOT]. (2012). Adapting to a changing climate: Statewide study of climate-related infrastructure risks. Retrieved from http://www.wsdot.wa.gov/NR/rdonlyres/ 2F436F57-CFA9-420B-AE31-807197DD5356/ 0/AdaptationFolioNov8.pdf

Wisconsin Initiative on Climate Change Impacts [WICCI]. (2011). Wisconsin's changing climate: Impacts and adaptation. Madison, Wisconsin: Nelson Institute for Environmental Studies, University of Wisconsin-Madison and the Wisconsin Department of Natural Resources. Retrieved from http://www.wicci.wisc.edu/publications.php 
Wortham, J., \& Miller, C. C. (2013, April 29). Venture capitalists are making bigger bets on food start-ups. New York Times, p. B1. Retrieved from http://www.nytimes.com/2013/04/29/business/ venture-capitalists-are-making-bigger-bets-on-foodstart-ups.html

Wortman, S. E., Francis, C. A., Galusha, T. D., Hoagland, C., Van Wart, J., Baenziger, P. S., ... Johnson, M. (2013). Evaluating cultivars for organic farming: Maize, soybean, and wheat genotype by system interactions in eastern Nebraska. Agroecology and Sustainable Food Systems, 37(8), 915-932.

http://dx.doi.org/10.1080/21683565.2013.764956

Zurayk, R. (2012). Asking the right questions. Journal of Agriculture, Food Systems, and Community Development, 3(1), 17-19.

http://dx.doi.org/10.5304/jafscd.2012.031.018 